\title{
The Impact of Ghana's Higher Education Governance and Regulatory Framework on Financial Sustainability
}

\author{
Justice Ray Achoanya Ayam
}

\begin{abstract}
Higher Education governance, legal and regulatory regimes in Ghana are important factors in the complex Higher Education landscape and its attendant funding challenges. Increased global demand for Higher Education highlights the importance of this framework in ensuring sustainable funding of the sector. The study assessed the impact of governance and regulatory variables on financial sustainability using a quantitative research methodology and a well-validated research instrument for correlational analysis. The findings revealed a statistically significant relationship between the combined effect of all eight variables while the variable, institutions undergo accreditation was the only one that was significant in predicting the best fit equation for financial sustainability. The recommendations arising from the findings will assist policy-makers to undertake relevant reform of the current governance, legal and regulatory practices in the country.
\end{abstract}

Key words: financial sustainability, governance, legal and regulatory framework, Ghana public universities, higher education institutions

Les régimes légaux, de régulation, et de gouvernance de l'Enseignement Supérieur au Ghana sont d'importants facteurs dans le paysage complexe de l'Enseignement Supérieur et ses défis corollaires de financement. L'augmentation de la demande internationale en enseignement supérieur souligne l'importance de ce cadre qui garantit la durabilité du financement pour le secteur. Cette étude évalue l'impact des variables de gouvernance et de régulation sur la viabilité financière en utilisant une méthodologie

ABOUt THE AUthors: JUSTICE RAY ACHOANYA AYAM Catholic University College of Ghana, Fiapre, Brong-Ahafo, Ghana. Email: ajrayam@yahoo.com 
de recherche quantitative et un instrument de recherche bien validé pour l'analyse de corrélation. Les résultats révèlent une relation statistiquement considérable entre l'effet combiné des huit variables tandis que la variable « institutions soumises à l'habilitation » est la seule signifiante pour prédire la meilleure équation en termes de viabilité financière. Les recommendations dégagées à partir des résultats encourageront les acteurs politiques à engager une réforme profonde et pertinente des pratiques actuelles légales, régulatrices et de gouvernance dans le pays.

\section{Background}

\section{Higher Education Governance, Legal and Regulatory Frameworks}

The Higher Education (HE) governance, legal and regulatory framework is an important factor in ensuring this sector's financial sustainability. Loose oversight of Higher Education Institutions (HEIs) may give rise to poor quality education with minimal return on investment to students, parents and guardians, the general public and the overall economic development of the country (Erkkilä and Piironen, 20I4). Furthermore, demands for increased accountability by the state, students, parents, guardians and partners of HEIs have become more pronounced as these institutions continue to look to these stakeholders for funding. It is against this backdrop that the study assessed the impact of Ghana's HE governance and regulatory framework on financial sustainability.

Governance comprises decision-making structures and processes, formulation and implementation of policies to guide the work of institutions, and the rules and processes by means of which universities govern their affairs (Hladchenko, Antonowicz, and de Boer, 20I7; Kwiek, 20I5; Shattock, 20I3). Good governance calls for sound leadership that focuses on academic freedom, participatory governance, accountability and the quest to achieve academic excellence. Effah (20I5) identified a number of HE governance models, including the continental (European) model; the British (collegial) model; the American university model; and the Chinese model. A critical review of these models points to the common desire to achieve academic freedom and enhance autonomy, as well as promote research and knowledge acquisition. Williams (2015) and Collins (2014) observe that inappropriate and outdated governance and management practices may result in tertiary institutions not fulfilling their mission, while Teferra (2013) points to flaws in the management and planning capacities of university administrators.

The legal and regulatory framework for HE should thus promote flexibility, autonomy, and accountability. These frameworks vary widely from country to country. Owusu-mensah (20I5) notes that regulation enhances competitiveness and management efficiency, enables HEIs to manage market forces and fosters higher levels of achievement. However, it has the tendency to dampen entrepreneurship and innovation (Jogn and Wittenloostuijn, 20I4). Furthermore, Shah (20I5) states that private HEIs confront unique legal challenges, including a lack of clarity on the role of the private sector in the education system; complex registration processes; unclear and subjective criteria and standards to qualify for registration; and outdated accreditation criteria. The legal framework also imposes limits on private institutions' ability to charge market-related fees. Finally, Monyoncho (20I5) observes that HEIs' scope and ability to moblise, allocate and utilise resources are determined by the prevailing legal and regulatory environment.

Previous studies mainly focused on corporate governance's impact on accountability, integrity, and fairness, rather than financial performance and sustainability. This study sought to fill this gap by examining how Ghana's governance and regulatory framework for HE impacts on public HEIs' financial sustainability.

\section{Higher Education in Ghana}

Ghana's HE system has witnessed significant expansion leading to astronomic growth in access and participation. The sector is made up of public and private universities and university colleges, professional institutions, colleges of education and agriculture, and nurses' training colleges. The Ministry of Education (20I5) notes that the number of HEIs increased from II9 in the 20IO/2OII academic year to 128 in the $2013 / 2014$ academic year (see Figure I below).

Figure 1. Tertiary Institutions in Ghana

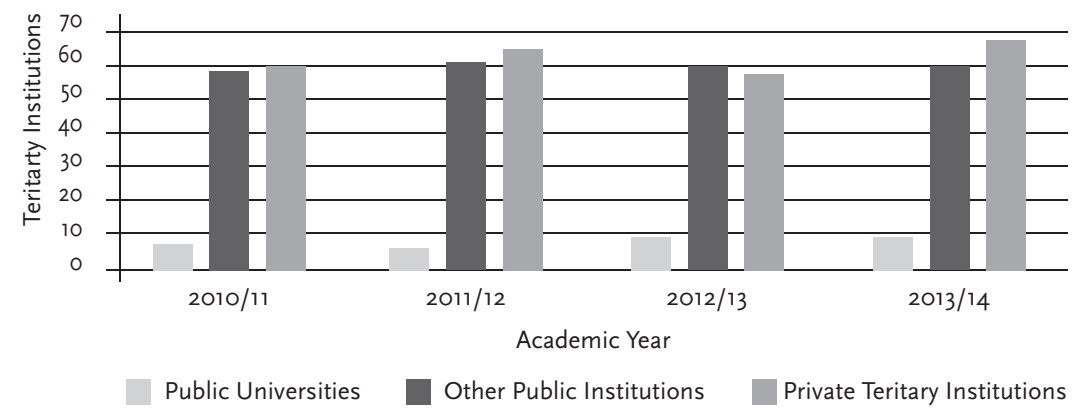

Source: Author's analysis of data from the 2015 Education Sector Performance Report of the Ministry of Education, Chana 
Atuahene and Owusu-ansah (2013) note that, apart from these accredited institutions, several non-accredited organisations offer tertiary courses in Ghana. Expansion has triggered some competition despite growing demand for access to tertiary education. As noted by Yudkevich (20I7), access remains a global concern. The government of Ghana's quest to expand access resulted in the establishment of additional universities in the Brong Ahafo and Volta Regions, with a third in the Eastern Region and the conversion of all polytechnics into technical universities. Policy reforms have also created a favourable environment for private sector participation (Collins, 20I4).

\section{Enrolment and Participation}

Tertiary education in Ghana has recorded tremendous growth in the past decade and by the 20I3/20I4 academic year, gross enrolment had increased to $3 \mathrm{I3}, 846$ (Ghana MOE, 20I5). Enrolment grew by $8 \%$ over a ten-year period, compared with an average increase of $6.3 \%$ in sub-Saharan Africa (Knight, 20I4; UNESCO Institute for Statistics, 20I8). This can be attributed to major policy reforms since I992. Mohamedbhai (20I4)"mend eley": “'formattedCitation":"(Mohamedbhai, 20I4 notes that these include the reduction in the number of years of secondary schooling from I7 to I2: public-private partnerships which culminated in the opening of private universities and professional institutions; the upgrading of public specialised colleges to degree awarding institutions; the decision to upgrade polytechnics into technical universities; and the establishment of the Ghana Education Trust (GETFund) to fund academic infrastructure and promote research. Figure 2 below traces enrolment trends in tertiary education between the 20I0/20II and 2013/20I4 academic years.

Figure 2. Enrollment in Tertiary Institutions

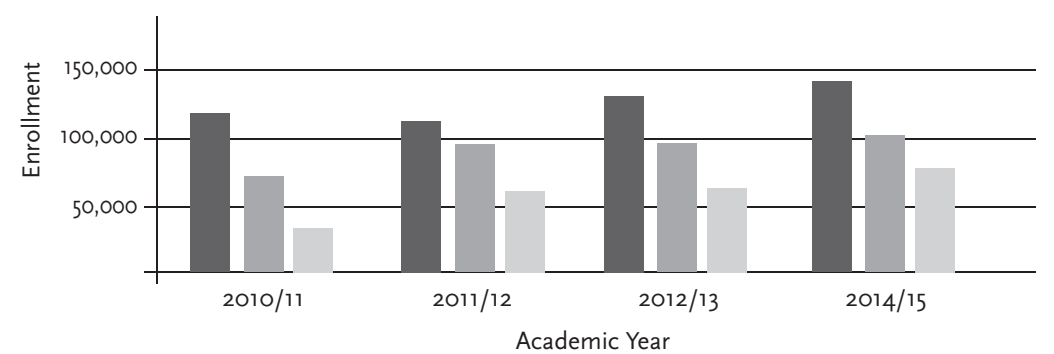

Public Universities

Academic Year

Source: Author's analysis of data from the 2015 Education Sector Performance Report of the Ministry of Education, Ghana
Despite the surge in enrolment, access and participation rates remain low. According to the UNESCO Institute for Statistics (20I8a), gross enrolment in tertiary education in the $2015 / 2016$ academic year was $16.07 \%$ of Ghana's tertiary school going age population of $2,627, \mathrm{I} 66$, resulting in a huge access gap of $83.93 \%$. The gap declined from $87.91 \%$ in $2010 / 2011$ to $83.77 \%$ in $2014 / 2015$ but recorded a marginal increase of $0.04 \%$ in the 20I5/20I6 academic year. While pre-tertiary level policy reforms led to a significant expansion in senior high school enrolment, corresponding initiatives to expand tertiary institutions' facilities to accommodate the anticipated growth were not forthcoming.

Furthermore, Ghana continues to record low levels of female participation in HE. Figure 3 below provides a breakdown of gross male and female enrolment trends from $201 \mathrm{I}$ to $20 \mathrm{I} 6$.

Figure 3. Gender Breakdown of Gross Enrolment in HE in Ghana

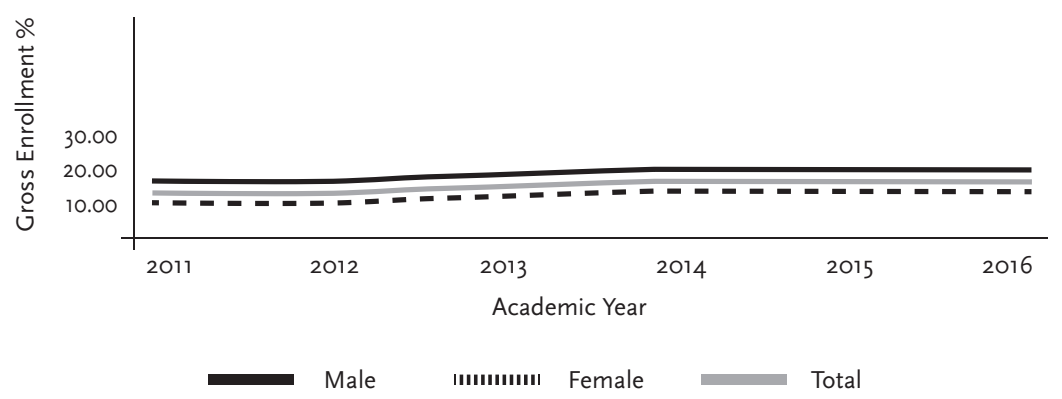

Source: United Nations Education Scientific and Cultural Organisation (UNESCO) Institute for Statistics, 2018

\section{Internationalisation}

Teferra (20I4) notes that, in a knowledge economy, internationalisation is regarded as having a positive impact on the quality of $\mathrm{HE}$ and its research, as well as regionalisation and global integration, and improved human resource capacity. Enrolment of international students, mainly from the West African sub-region, is gradually transforming Ghana's HE landscape. Knight (20I4) notes that increased collaboration among national government and regional groupings will trigger growth in student mobility and increased internationalisation. The National Accreditation Board of Ghana noted that Io,788 international students were enrolled at the country's universities and colleges in the $2012 / 2013$ academic year with $69 \%$ coming from Nigeria, resulting in significant economic benefits. Figure 4 below presents international students' enrolment in the 20I2/2013 academic year. 
Figure 4. 2012/2013 International Students' Enrolment in Ghana

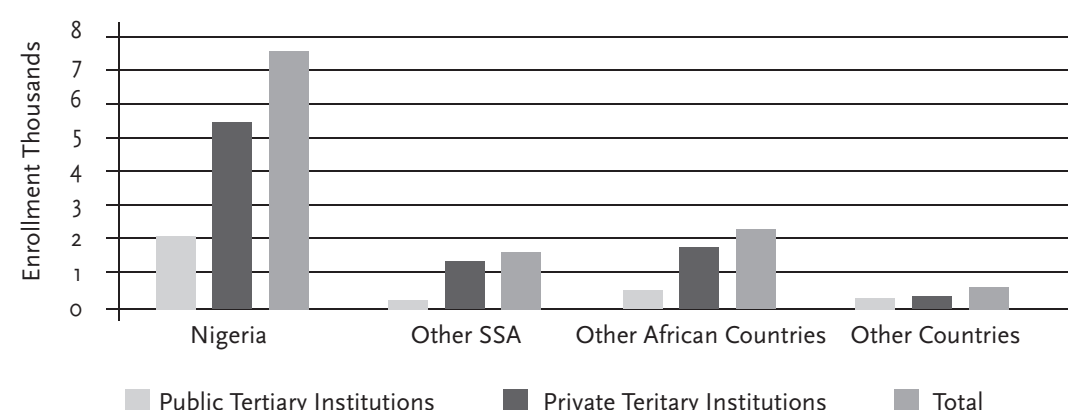

Source: Author's analysis based on data from the NAB Tertiary Education Institutional statistical report for the 2012/2013 academic year

\section{Legal and Regulatory Framework}

Increased massification of $\mathrm{HE}$ and the influence of the knowledge economy (Bezuidenhout, De Jager, and Naidoo, 20I3; Ellis and Steyn, 20I4; OECD, 20I6), among other factors, have prompted countries to strengthen legal and regulatory regimes in this sector. Most centre on minimal government intervention while encouraging increased private participation. The phenomenal growth in the number of private providers across Africa has been influenced by demand for increased access to HE (Hayward and Ncayiyana, 20I4). This could result in exploitation of consumers of their services as well as compromise the quality of the programmes on offer. Given that the quality of available human capital is crucial for the economic development of any nation, a level of regulation is required to guide the conduct of HEIs in critical areas, such as the pricing of academic programmes, and the quality of service delivery and academic research. Countries across the globe have promulgated laws and established regulatory institutions (Owusu-mensah, 20I5) to develop and implement guidelines to regulate public and private HEIs.

The government of Ghana has engaged stakeholders in dialogue and discussions leading to increased reforms in HE. The country's legal and regulatory framework includes Article 25c of the 1992 Constitution of the Republic of Ghana, which stipulates that HE shall be made accessible through the progressive introduction of free education. The Ministry of Education regulates the provision of $\mathrm{HE}$ through the following legislative instruments: the National Council for Tertiary Education (NCTE) Act 454 of I993: the National Accreditation Board (NAB) Act 754 of 2007: the National Board for Professional and Technical Examinations (NABTEX) Act 492 of I994: the Council for Technical, Vocational Education (COTVET) Act 7I8 of 2006; and the Ghana Education Trust Fund Act 479 of 2000 (NCTE, 20I2). As in other countries, the regulatory regime seeks to ensure that, HEIs offer quality education, prospective students and the public are not exploited by providers, qualifications are well aligned with national standards, and private institutions comply with national accreditation standards (Ellis and Steyn, 20I4).

This article focuses on corporate governance and regulatory practices at public universities in Ghana and their impact on financial sustainability.

\section{Methods}

\section{Research Design}

The study adopted the positivist research paradigm which was widely used in previous studies (Afriyie, 20I5; Cernostana, 20I7; Lucianelli and Citro, 20I7; Sazonov et al., 20I5). As noted by Saunders, Lewis, Thornhill, and Bristow (20I5), in this paradigm the researcher assumes the role of an objective analyst who makes detached interpretations of the data collected. Based on the empirical data, this enables generalised predictions to be made (Creswell and Creswell, 20I7; Lyon, Mšllering, and Saunders, 20I5) as well as quantifiable observations that support statistical analysis.

A quantitative research technique was employed to analyse the relationship and to test the hypothesis between the dependent and independent variables. Previous studies in HE (Bhayat, 20I5; Cernostana, 20I7; Chatama, 20I4; Sazonov et al., 20I5) alluded to the relevance of this research technique and the significance of the independent variable's related statements on the governance and regulatory framework to the dependent variable. The research questions and their related hypotheses focused on: (a) the relationship between individual statements on the governance and regulatory framework and financial sustainability; (b) the relationship between the combined statements on the governance and regulatory framework and public universities' financial sustainability; and (c) the combined statements' contribution in achieving the best fit equation model for public universities' financial sustainability. A quantitative survey instrument was employed and emails were sent to experts, mainly Vice-Chancellors or their deputies, and top management in the finance, internal audit and registry departments of the sampled public universities. The first round of the instrument validation was undertaken among 20 subject area experts and feedback received was incorporated in the instrument. The modified instrument was piloted with a second different set of Io subject area expects, with feedback also incorporated, thus confirming the validity of the research instrument before administration.

A test-retest reliability was undertaken among io participants from the sample over a period of seven days to test the consistency of their responses. 
The reliability test results produced an acceptable coefficient $(r=.723)$, well above the threshold of $r \geq 0.5$ (Creswell and Creswell, 20I7).

A five-point Likert-scale web-based survey instrument was employed to organise the participants' options in a symmetrical and balanced scale reflecting the degree of agreement (Simms, Zelazny, Williams, and Bemstein, 20I9). The participants were contacted telephonically, followed by an email with a link to the web-based survey instrument. Schoenherr, Ellram, and Tate (2015) note that this approach is more convenient and faster than other means of administering questionnaires. The data analysis comprised descriptive, correlation and multiple regression analysis. The correlation (Lyon, Mšllering, and Saunders, 20I5) and the adjusted coefficient of determination $\mathrm{R} 2$ computed from the regression analysis measured how well the multiple regression fitted the population sample (Triola, 20I7).

MYSQL, SPSS version 25 and Excel were used to store, organise and produce the statistical analysis. The statements employed to analyse the relationship using correlation and multiple regression analysis were based on previous studies which emphasised their significance with regard to financial sustainability in the HE sector (Amir, Auzair, Maelah, and Ahmad, 20I6; Erins and Erina, 20I7; Marovah, 20I5; Moghadam, Jorge, and Pirzade, 20I7)this report is another milestone in EUA's work on financial sustainability, in particular, the development of full costing. EUA has since then carried out a variety of studies and held many events which also contributed to a better understanding of the current funding challenges for universities. Following a growing awareness that full costing is an important tool to address these funding challenges and an increased demand for relevant expertise and assistance, EUA began to coordinate the EUIMA cooperation initiative ('European Universities Implementing their Modernisation Agenda'.

\section{Population and Sample Strategy}

The study population comprised Vice-Chancellors, pro Vice-Chancellors, registrars, deputy registrars, finance directors, deputy finance directors, directors of internal audit, deputy directors of internal audit, management accountants, budget officers, systems accountants and quality assurance officers from the seven sampled public universities established in or before I998. The computed target sample size at 95\% confidence level was 85 out of the population of 220 experts from the public universities in Ghana. The response rate was $62.35 \%$ (53 valid responses). The sample size of 85 thus offered sufficient representation of experts.

\section{Results and Discussion \\ Demographic Statistics}

The demographic characteristics comprised both individual and institutional details. The participants' demographic characteristics included their institution's name, their current position, age group, gender, academic or professional qualifications, and relevant professional experience. The participating institutions' demographic details covered the student population and accreditation status.

The positions held by the participants were skewed towards functional and middle level management. The highest number of responses of $n=20$ $(37.73 \%)$ were received from functional level management while the lowest of $n=\mathrm{I} 4(26.42 \%)$ were obtained from executive management. The age bracket, 4I to 50, had the largest number of participants of $n=23$, representing $43.40 \%$, mainly as a result of the level of expertise required of the participants. The participants' gender was significantly skewed towards males with 44 males and nine females. Most of the participants' held academic or professional qualifications that were appropriate for executive management positions. A large number of participants $(n=33)$ representing $62.26 \%$ had undergraduate, master's and professional qualifications, I3 $(24.53 \%)$ had undergraduate and master's qualifications, six (II.32\%) had undergraduate, master's and PhD qualifications and one (1.87\%) had masters and other qualifications. The participants' professional experience also aligned well with their positions. The majority $(n=32)$ representing $60.38 \%$ had II or more years' relevant professional experience; three $(5.66 \%)$ had relevant experience of 6 to io years, and I3 and five had 5 years or less and more than 20 years' relevant professional experience, respectively (see Table 4 in Appendix I).

\section{Descriptive Statistics}

The results of the descriptive analysis showed that the statement: legal or regulatory framework promotes quality of admission, academic delivery and examinations, was rated highly significant by the participants $(M=$ 4.I3, $S D=0.79)$. The mean values of the following statements: legal or regulatory framework promotes recruitment of competent staff and staff training and development; legal or regulatory framework promotes good governance and management efficiency; legal or regulatory framework ensures academic programmes are accredited in accordance with best practices; legal or regulatory framework requires universities to undergo institutional accreditation in accordance with best practices; and the Acts establishing your university promote autonomy and academic freedom, were fairly distributed $(M=3.92, S D=0.76),(M=4.00, S D=0.57),(M=$ 4.19, $S D=0.83),(M=4.08, S D=0.94)$ and $(M=4.00, S D=0.86)$, while the 
statement, regulatory institutions in Ghana assess university performance against benchmarks and publish their performance rankings regularly ( $M$ $=2.50, S D=1.42$ ) had the lowest rating among the participants. The variance and range of this statement were significant $($ Var $=2.02$, Range $=$ 4.00) and had a dispersion of 0.86 compared to the rest of the statements. The test of skewness between the statements were adequately normal for the purpose of this study. Table I provides the details.

Table 1. Participants' overall Response Ratings

\begin{tabular}{|l|l|l|l|l|l|l|}
\hline Variable & $\mathrm{n}$ & $\mathrm{M}$ & $\mathrm{SD}$ & $\mathrm{Var}$ & Range & Skewness \\
\hline $\begin{array}{l}\text { The regulatory framework promotes quality } \\
\text { of admission, academic delivery, and } \\
\text { examinations. }\end{array}$ & 53 & 4.13 & 0.785 & 0.617 & 4 & -1.478 \\
\hline $\begin{array}{l}\text { The regulatory framework promotes } \\
\text { recruitment of competent staff and staff } \\
\text { training and development. }\end{array}$ & 53 & 3.92 & 0.756 & 0.571 & 4 & -1.262 \\
\hline $\begin{array}{l}\text { The regulatory framework promotes good } \\
\text { governance and management efficiency. }\end{array}$ & 53 & 4.00 & 0.784 & 0.615 & 4 & -1.490 \\
\hline $\begin{array}{l}\text { The regulatory framework ensures } \\
\text { academic programmes are accredited in } \\
\text { accordance with best practices. }\end{array}$ & 53 & 4.19 & 0.833 & 0.694 & 4 & -1.616 \\
\hline $\begin{array}{l}\text { The regulatory framework requires } \\
\text { universities to undergo institutional } \\
\text { accreditation in accordance with best } \\
\text { practices. }\end{array}$ & 53 & 4.08 & 0.937 & 0.879 & 4 & -1.610 \\
\hline $\begin{array}{l}\text { The Act(s) establishing your university } \\
\text { promote autonomy and academic freedom. }\end{array}$ & 53 & 4.00 & 0.855 & 0.731 & 4 & -1.152 \\
\hline $\begin{array}{l}\text { The regulatory institutions in Chana assess } \\
\text { university performance against benchmarks } \\
\text { and publish their performance rankings } \\
\text { regularly }\end{array}$ & 52 & 2.50 & 1.421 & 2.020 & 4 & 0.405 \\
\hline
\end{tabular}

\section{Correlation Analysis}

The correlation results showed different levels of positive correlation between the independent variable statements relating to the governance and regulatory framework, and the dependent variable of financial sustainability. The Pearson's rank correlation results showed that five statements: legal or regulatory framework promotes quality of admission, academic delivery and examinations; legal or regulatory framework promotes recruitment of competent staff and staff training and development; legal or regulatory framework promotes good governance and management efficiency; legal or regulatory framework ensures academic programmes are accredited in accordance with best practices; and legal or regulatory framework requires universities to undergo institutional accreditation in accordance with best practices, showed large positive correlation effects of $r=.586, r=.564, r=.508, r=.545$ and $r=.579$, respectively. For details see Table 2 below.

\begin{tabular}{|c|c|c|c|c|c|c|c|c|c|c|}
\hline is & $\begin{array}{l}\stackrel{n}{+} \\
\dot{f}\end{array}$ & 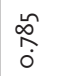 & 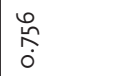 & 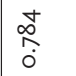 & $\begin{array}{c}\tilde{\infty} \\
\infty \\
0\end{array}$ & $\mid \begin{array}{l}\hat{n} \\
\hat{o} \\
0\end{array}$ & $\begin{array}{c}n \\
\omega \\
\infty \\
0 \\
0\end{array}$ & $\stackrel{\bar{y}}{\check{Y}}$ & & \\
\hline$\Sigma$ & $\underset{\hat{N}}{\hat{N}}$ & $\stackrel{m}{\dot{f}}$ & مू & $\begin{array}{l}\circ \\
\dot{+}\end{array}$ & $\frac{\sigma}{\dot{j}}$ & \begin{tabular}{|l}
$\infty$ \\
0 \\
$\dot{+}$
\end{tabular} & $\begin{array}{l}\stackrel{\circ}{0} \\
\dot{+}\end{array}$ & 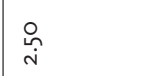 & & \\
\hline$\infty$ & 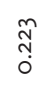 & $\begin{array}{l}\text { ô } \\
\text { ô }\end{array}$ & $\begin{array}{l}\hat{N} \\
\tilde{O} \\
0\end{array}$ & 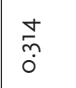 & 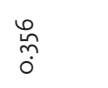 & 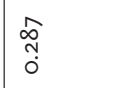 & $\begin{array}{c}\infty \\
\infty \\
0 \\
0\end{array}$ & & $\stackrel{\circ}{\stackrel{\circ}{i}}$ & $\stackrel{\bar{y}}{-}$ \\
\hline$n$ & 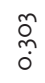 & $\begin{array}{l}\hat{0} \\
0 \\
0\end{array}$ & $\begin{array}{l}0 \\
0 \\
0 \\
0\end{array}$ & 站 & $\begin{array}{l}\hat{\sigma} \\
0 \\
0\end{array}$ & 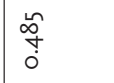 & & $\begin{array}{c}\infty \\
\infty \\
0 \\
0\end{array}$ & $\stackrel{\circ}{\circ}$ & $\begin{array}{l}\text { L } \\
\infty \\
0\end{array}$ \\
\hline 6 & $\begin{array}{l}\mathfrak{r} \\
\hat{i} \\
0\end{array}$ & $\begin{array}{l}\overline{\tilde{m}} \\
\dot{0}\end{array}$ & $\begin{array}{l}\stackrel{0}{0} \\
0 \\
0\end{array}$ & $\begin{array}{l}0 \\
0 \\
0 \\
0 \\
0\end{array}$ & $\begin{array}{l}\text { a } \\
0 \\
0 \\
0\end{array}$ & ' & $\begin{array}{c}\tilde{n} \\
\infty \\
0 \\
0\end{array}$ & $\begin{array}{c}\hat{\infty} \\
\sim \\
0\end{array}$ & $\begin{array}{l}\infty \\
0 \\
\dot{j}\end{array}$ & ô \\
\hline in & 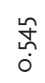 & $\begin{array}{l}\sigma \\
\infty \\
0 \\
0\end{array}$ & 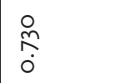 & $\begin{array}{l}\bar{\alpha} \\
\infty \\
0\end{array}$ & . & $\begin{array}{l}\sigma \\
2 \\
0 \\
0\end{array}$ & $\begin{array}{l}\hat{N} \\
\tilde{O} \\
0\end{array}$ & 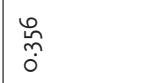 & $\stackrel{\sigma}{\dot{r}}$ & $\begin{array}{c}\tilde{O} \\
0 \\
0\end{array}$ \\
\hline$\nabla$ & $\begin{array}{l}\infty \\
\stackrel{0}{0} \\
\stackrel{0}{0}\end{array}$ & $\begin{array}{c}n \\
\infty \\
\infty \\
0\end{array}$ & $\underset{i}{\stackrel{\Omega}{\delta}}$ & 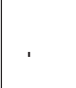 & $\begin{array}{l}\bar{\delta} \\
\infty \\
0\end{array}$ & \begin{tabular}{|l}
0 \\
$\infty$ \\
0 \\
0 \\
0
\end{tabular} & 点 & 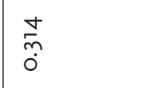 & $\underset{+}{\stackrel{+}{+}}$ & $\begin{array}{l}\stackrel{+}{0} \\
\stackrel{0}{0}\end{array}$ \\
\hline$m$ & 草 & $\begin{array}{l}\tilde{D} \\
\infty \\
0 \\
0\end{array}$ & ' & $\underset{\hat{i}}{\stackrel{\Upsilon}{\hat{0}}}$ & 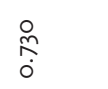 & $\begin{array}{l}0 \\
0 \\
0 \\
0 \\
0\end{array}$ & $\begin{array}{l}\stackrel{0}{0} \\
\stackrel{\leftrightarrow}{0} \\
0\end{array}$ & 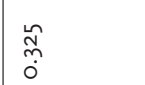 & $\underset{\sim}{\tilde{m}}$ & $\begin{array}{l}\stackrel{0}{\circ} \\
0\end{array}$ \\
\hline$N$ & 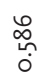 & ' & $\begin{array}{l}\text { D̃ } \\
\infty \\
0 \\
0\end{array}$ & $\begin{array}{c}\sim \\
\infty \\
\infty \\
0\end{array}$ & $\begin{array}{l}\text { న } \\
\infty \\
0\end{array}$ & $\begin{array}{l}\overline{\hat{m}} \\
\dot{0}\end{array}$ & $\begin{array}{l}\hat{\delta} \\
b \\
0\end{array}$ & $\begin{array}{l}\text { જે } \\
\text { †े }\end{array}$ & $\stackrel{m}{\dot{r}}$ & \begin{tabular}{l}
$\stackrel{\infty}{\infty}$ \\
\multirow{0}{0}{}
\end{tabular} \\
\hline - & ' & $\begin{array}{l}\stackrel{\infty}{0} \\
\stackrel{0}{0} \\
0\end{array}$ & 苦 & $\begin{array}{l}\infty \\
0 \\
0 \\
0 \\
0\end{array}$ & 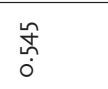 & 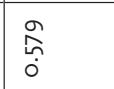 & 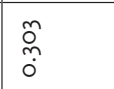 & $\begin{array}{l}\tilde{N} \\
\text { ஸे }\end{array}$ & $\stackrel{\hat{N}}{\hat{N}}$ & $\stackrel{\stackrel{L}{\circ}}{\dot{f}}$ \\
\hline \multirow{2}{*}{$\begin{array}{l}\frac{0}{0} \\
\frac{\pi}{\pi} \\
\frac{\pi}{\pi}\end{array}$} & 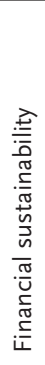 & 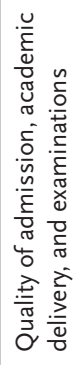 & 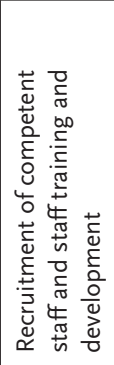 & 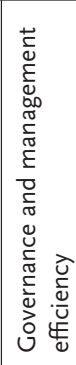 & 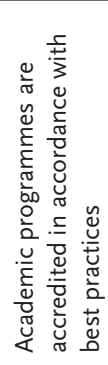 & 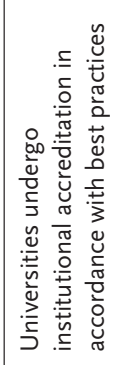 & 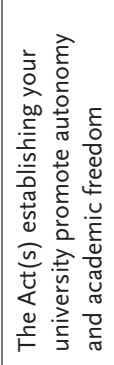 & 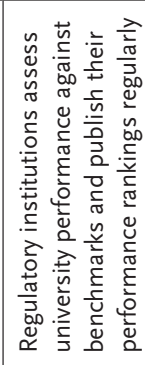 & & \\
\hline & - & N & $m$ & ナ & in & 6 & $\wedge$ & $\infty$ & $\Sigma$ & in \\
\hline
\end{tabular}




\section{Regression Coefficient}

The regression results tested the significance levels of the established factors with the correlation results and enabled a regression equation to be derived for financial sustainability (). The coefficient of determination $\left(R^{2}\right)$ and the $p$ value enabled the best-fit equation to be determined. The multiple regression results yielded a coefficient of $r=.687, F(7,47)=76.87$, $p=.000, R^{2}=.472$. From the analysis (see Table 3), only one statement (the legal or regulatory framework requires universities to undergo institutional accreditation in accordance with best practices) was significant in predicting financial sustainability with $\mathrm{p}$ values $p=.0 \mathrm{I} 4$ and beta weights of .406. The remainder of the statements: legal or regulatory framework promotes quality of admission, academic delivery, and examinations ( $p$ $=.062$ ); legal or regulatory framework promotes recruitment of competent staff and staff training and development $(p=.319)$; legal or regulatory framework promotes good governance and management efficiency $(p=$ .I73); legal or regulatory framework ensures academic programmes are accredited in accordance with best practices $(p=.899)$; the Acts establishing your university promote autonomy and academic freedom ( $p=. \mathrm{I} 65)$ and regulatory institutions in Ghana assess university performance against benchmarks and publish their performance rankings regularly $(p=.3 \mathrm{I} 6)$; were not significant and thus could not be considered in determining the best-fit model as their $p$ values were above the threshold of $p<.05$. The results thus showed that there was a significant relationship between the statement, legal or regulatory framework requires universities to undergo institutional accreditation in accordance with best practices relating to the independent variable and the dependent variable (financial sustainability) at $F(7,47)=76.87, p=.000, R^{2}=.472$.

\section{Results of the Regression Analysis}

The results of the regression analysis showed varied results from the correlation analysis in relation to the statements with significant outcome and the degree of positive correlation. The best fit regression equation for financial sustainability is:

$Y F S=\mathrm{a}+\beta G I A$,

Where $Y F S=$ financial sustainability (predictor variable), $\mathrm{a}=$ constant value

$\beta G I A=$ legal or regulatory framework requires universities to undergo institutional accreditation in accordance with best practices (independent variable statement).

Hence the regression equation for $Y F S=7.151+0.433 \beta G I A$.
The regression analysis determined the best regression equation by including all statements with coefficients higher than zero and $p$ values of $p<.05$ significance level and which further supported the rejection of the null hypothesis $\left(\mathrm{H}_{\mathrm{o}}\right)$ : there is no relationship between the combined effect of governance and regulatory framework statements and public universities' financial sustainability.

\begin{tabular}{|c|c|c|c|c|c|c|c|c|}
\hline a & $\begin{array}{l}\tilde{\tilde{O}} \\
\text { Oे } \\
\dot{0}\end{array}$ & $\begin{array}{l}\tilde{O} \\
\stackrel{0}{0} \\
0\end{array}$ & $\stackrel{\sigma}{\tilde{m}}$ & $\stackrel{m}{\hat{0}}$ & $\begin{array}{l}\text { Oे } \\
\infty \\
0 \\
0\end{array}$ & $\begin{array}{l}0 \\
0 \\
\end{array}$ & $\frac{\tilde{\sigma}}{\stackrel{0}{0}}$ & $\begin{array}{l}0 \\
\infty \\
0 \\
0\end{array}$ \\
\hline$\vdash$ & 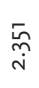 & ڤે & $\begin{array}{l}\stackrel{\infty}{\circ} \\
\stackrel{+}{-}\end{array}$ & 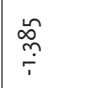 & $\frac{\widehat{N}}{0}$ & 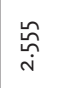 & $\begin{array}{c}m \\
\dot{f} \\
\dot{T}\end{array}$ & 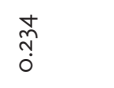 \\
\hline 웅 & $\begin{array}{l}\stackrel{N}{N} \\
\stackrel{n}{m}\end{array}$ & $\stackrel{\circ}{\stackrel{\circ}{r}}$ & $\begin{array}{l}\hat{\sigma} \\
\dot{m} \\
\dot{n}\end{array}$ & $\begin{array}{l}0 \\
\stackrel{\circ}{\circ} \\
\stackrel{-}{0}\end{array}$ & $\begin{array}{l}\mathcal{F} \\
6 \\
\dot{m}\end{array}$ & $\begin{array}{l}\infty \\
0 \\
0 \\
\dot{n}\end{array}$ & \begin{tabular}{l}
$\hat{o}$ \\
\multirow{3}{0}{} \\
0
\end{tabular} & $\begin{array}{c}\text { n. } \\
\infty \\
0 \\
0\end{array}$ \\
\hline 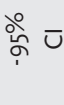 & $\begin{array}{l}\stackrel{O}{N} \\
\stackrel{N}{-}\end{array}$ & $\begin{array}{l}\stackrel{8}{\circ} \\
\frac{0}{1}\end{array}$ & 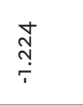 & $\begin{array}{c}\bar{R} \\
\dot{i}\end{array}$ & $\begin{array}{l}\stackrel{0}{r} \\
\end{array}$ & 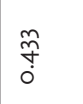 & $\begin{array}{l}\widehat{\hat{N}} \\
\text { în } \\
\end{array}$ & 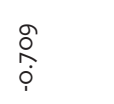 \\
\hline$\infty$ & & $\begin{array}{l}\stackrel{n}{b} \\
\dot{0} \\
0\end{array}$ & $\frac{\hat{\sigma}}{0}$ & 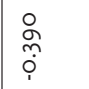 & $\begin{array}{c}\infty \\
\tilde{O} \\
0 \\
0\end{array}$ & $\begin{array}{l}\stackrel{0}{0} \\
\vdots \\
0\end{array}$ & $\begin{array}{l}\stackrel{m}{n} \\
\stackrel{p}{i}\end{array}$ & $\begin{array}{l}\infty \\
\stackrel{0}{0} \\
\dot{0}\end{array}$ \\
\hline $\begin{array}{l}\dot{\bar{g}} \\
\text { 岀 } \\
\dot{\vec{D}} \\
\dot{\omega}\end{array}$ & $\begin{array}{l}y \\
\text { o } \\
\dot{m}\end{array}$ & $\stackrel{\stackrel{\sim}{\alpha}}{\stackrel{\gamma}{r}}$ & $\stackrel{+}{\underset{T}{+}}$ & $\begin{array}{l}0 \\
\stackrel{\infty}{\infty} \\
\stackrel{\Gamma}{\circ}\end{array}$ & $\stackrel{\circ}{\stackrel{2}{\circ}}$ & $\begin{array}{l}\text { No } \\
\text { o } \\
0 \\
0\end{array}$ & 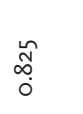 & 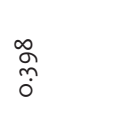 \\
\hline 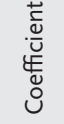 & $\stackrel{5}{i}$ & 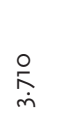 & 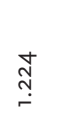 & 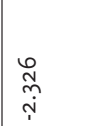 & \begin{tabular}{l}
0 \\
\cline { 1 - 1 } \\
0 \\
0
\end{tabular} & $\begin{array}{l}\overline{\tilde{L}} \\
\stackrel{\mathrm{i}}{\mathrm{j}}\end{array}$ & $\begin{array}{l}\stackrel{n}{0} \\
\stackrel{\longrightarrow}{T}\end{array}$ & $\begin{array}{l}\text { no } \\
0 \\
0\end{array}$ \\
\hline $\begin{array}{l}\frac{0}{0} \\
\frac{\sigma}{\frac{\pi}{5}} \\
\stackrel{5}{\frac{\pi}{5}}\end{array}$ & 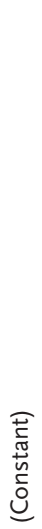 & 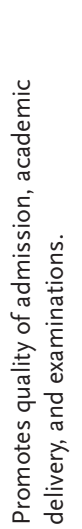 & 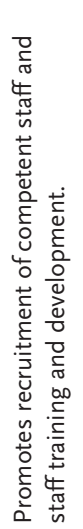 & 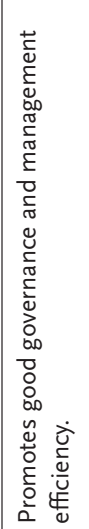 & 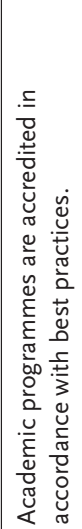 & 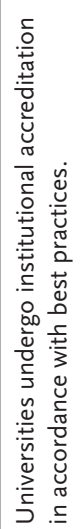 & 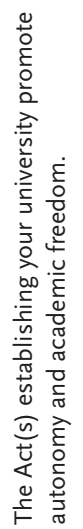 & 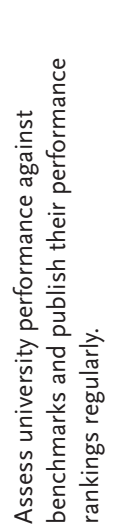 \\
\hline
\end{tabular}


The results show a statistical relationship between the governance and regulatory variable, the legal or regulatory framework requires universities to undergo institutional accreditation in accordance with best practices, and financial sustainability. Also in line with previous studies (Rowland, 20I7; Shah, 20I5; Shattock), the correlation results established mainly large positive correlation between the variables of the governance and regulatory framework and public universities' financial sustainability. Further analysis produced results that supported the rejection of the null hypothesis: $\mathrm{H}_{\text {。 }}$. The regression results illustrated a significant relationship between the governance and regulatory framework variable, the legal or regulatory framework requires universities to undergo institutional accreditation in accordance with best practices, and financial sustainability as postulated by Owusu-Mensah (20I5) and Hall (20I2)a Williams College economist, said that people investing in human capital by purchasing higher education do not know what they are buying and they cannot do anything until it is too late to act on it. Underwriters Laboratory (UL, which further enabled the best fit equation to be derived. The weak relationship established between the remaining governance and regulatory framework variables and financial sustainability contradict previous research findings (Collins, 20I4; Owusu-Mensah, 20I5; Tasopoulou and Tsiotras, 20I7; Teferra, 20I4).

These findings could assist HEIs, the government, government agencies, regulatory institutions and donor agencies to revisit the governance and regulatory framework with the aim of enhancing sustainable financing of HEIs in Ghana.

\section{Recommendations}

Based on the study's findings, it is recommended that:

I) The Ministry of Education review the current legislative framework governing HEIs in Ghana with a view to incorporating best practices drawn from the African system (Ellis and Steyn, 20I4) and the UK (Hogan, 20I5). The current legal regime does not enable these institutions to independently determine and fix fees for academic programmes, undermining the financial sustainability of such programmes.

2) Regulatory agencies could also revisit current regulatory practices with the aim of enhancing fairness and healthy competition among HEIs as practiced in South Africa (Ellis and Steyn, 20I4; Shah, 2015; Famade et al., 20I5). Issues relating to affiliations, attaining a charter and institutional and programme accreditation do not seem to be fair, particularly to private universities and university colleges.

3) The study revealed that the GETFund which is criterial for funding of infrastructure projects in HEIs does not promote transparency and accountability, and is open to political abuse (Kwasi-Agyeman, 20I5). It is recommended that the fund and the Ministry of Education conduct a review aimed at developing clear and transparent disbursement criteria for both public and private HEIs that are not-for-profit.

4) The Ministry of Education should direct funding towards addressing skills gaps in science and technology, and research. This may require funding to be allocated based on specific input needs or research outcomes rather than the current discretionary approach (Newman and Duwiejua, 20I5). Through the Ministry of Education and the NCTE, the government could develop transparent costing guidelines to guide HEIs in implementing fair and transparent full cost recovery systems for academic programmes and activities similar to those suggested by Estermann and Claeys-Kulik (2013).

\section{Suggestions for Further Research}

Relevant areas for further research include:

I) Replicating the study across public and private HEIs in Ghana or sampled HEIs in Africa. This would offer broader insight into the relationship between the variables and financial sustainability.

2) The scope of future studies could be broadened to include experts from the regulatory agencies, the Ministry of Education and HE think tanks.

3) Finally, future studies could employ factor analysis to determine the governance and regulatory framework's variables' relevance to financial sustainability. This could be useful in eliminating factors that are of less importance to HEIs' financial sustainability and focusing on critical factors to further establish their statistical significance.

\section{References}

Afriyie, A. O. (20I5). Financial Sustainability Factors of Higher Education: A Predictive Model. International Journal of Education Learning and Development 2(3), I7-38.

Al-Haddad, S., and Yasin, A. (2018). Governance Reform in Higher Education Institutions in the Arab World: An Institutional Initiative. Higher Education Governance in the Arab World, 83-I04.

Amir, A. M., Auzair, S. M., Maelah, R., and Ahmad, A. (20I6). Pricing for higher education institutions: a value-based approach. International Journal of Educational Management 30(6), 929-940.

Atuahene, F., and Owusu-ansah, A. (2013). A Descriptive Assessment of Higher Education Access, Participation, Equity, and Disparity in Ghana. Sage Open, I-I6. https://doi.org/IO.II77/2158244013497725

Bezuidenhout, G., De Jager, J. W., and Naidoo, V. (2013). Factors that influence students' choice of private higher education institutions. South 
African Journal of Higher Education 27(5), II8I-II96.

Bhayat, I. (20I5). University Budgeting Models and Impacts on Organisational Performance. Australia: Macquarie University.

Bingab, B. B. B., Forson, J. A., Mmbali, O. S., and Baah-Ennumh, T. Y. (20I6). The evolution of university governance in Ghana: Implications for education policy and practice. Asian Social Science 12(5), I-I4. https://doi.org/I0.5539/ass.vi2n5pI47

Cernostana, Z. (20I7). Financial sustainability for private higher education institutions. In $9^{\text {th }}$ International Conference on Applied Economics Contemporary Issues in Economy.

Collins, C. S. (20I4). An Overview of African Higher Education and Development. The Development of Higher Education in Africa: Prospects and Challenges, 2I-65. https://doi.org/ıo.IIo8/SI479-3679

Chatama, Y. J. (20I4). Financing of Higher Education: an evolution of Cost Sharing approach in Tanzania. Developing Country Studies 4(9), 86-97.

Creswell, J. W., and Creswell, J. D. (20I7). Research design: Qualitative, quantitative, and mixed methods approaches. Sage publications.

Effah. (20I5). Towards Quality Higher Education in Ghana. Senior Academic Leadership Training (SALT) Programme.

Erkkilä, T., and Piironen, O. (20I4). Shifting fundaments of European higher education governance: competition, ranking, autonomy and accountability. Comparative Education 50(2), I77-I9I.

Ellram, L. M., and Tate, W. L. (20I5). A Note on the Use of Survey Research Firms to Enable Empirical Data Collection. Journal of Business Logistics 36(3), 288-300. https://doi.org/Io.IIII/jbl.I2092

Ellis, M., and Steyn, G. (20I4). The Regulatory Context in Private Higher Education in South Africa. Mediterranean Journal of Social Sciences 5(20), 258-27I. https://doi.org/IO.590I/mjss.20I4.v5n20p258

Estermann, T., and Claeys-Kulik, A.L. (20I3). Financially Sustainable Universities: Full Costing - Progress and Practice. European University Association.

Estermann, T. (20I5). University Autonomy in Europe. Higher Education Trends (3), 28-32.

Famade, O. A., Omiyale, G. T., and Adebola, Y. A. (2015). Towards improved funding of tertiary institutions in Nigeria. Asian Journal of Humanities and Social Sciences 3(2), 83-90. https://doi.org/ISSN: 2320-9720

Ghana MOE. (2015). Education Sector Performance Report.

Ghana GETFund. Ghana Education Trust Fund Act 2000, Act 58I, Ministry of Education (2000). Republic of Ghana: Parliament of Ghana.

Hall, J. (2OI2). Higher Education Accreditation: Market Regulation or Government Regulation? Independent Review 17(2), 233-238.

Hayward, F., and Ncayiyana, D. (20I4). Confronting the challenges of graduate education in sub-Saharan Africa and prospects for the future. International Journal of African Higher Education 1(I), I73-2I6. https:// doi.org/https://doi.org/ıo.6oI7/ijahe.viii.5647

Hladchenko, M., Antonowicz, D., and de Boer, H. (20I7). Understanding the Changes of the Higher Education Governance in Poland and Ukraine. The University as a Critical Institution, 55-74.

Jogn, G., and Wittenloostuijn. (20I4). Regulatory red tape and firm performance. Public Administration 92(4), 34-51.

Knight, J. (20I4). Towards African Higher Education Regionalization and Harmonization: Functional, Organizational and Political Approaches. The Development of Higher Education in Africa: Prospects and Challenges 21, 347-373. https://doi.org/http://dx.doi.org/Io.IIo8/ Si479-3679(2013)0000021015

Kwiek, M. (20I5). The unfading power of collegiality? University governance in Poland in a European comparative and quantitative perspective. International Journal of Educational Development 43, 77-89.

Kwasi-Agyeman, F. (20I5). Organizing Higher Education Funding in Ghana: The Case of Ghana Education Trust Fund (GETFund). Doctoral dissertation, University of Oslo.

Lyon, F., Mšllering, G., and Saunders, M. N. (20I5). Handbook of research methods on trust. (2nd ed.). Edward Elgar Publishing. https://doi. org/10.4337/978I782547419

Marovah, T. (20I5). Higher Education and Philanthropy in Africa. In Higher Education Funding Excellence Conference (pp. I-I4).

Mohamedbhai, G. (20I4). Massification in Higher Education Institutions in Africa: Causes, Consequences, and Responses. International Journal of African Higher Education 1(I), 60-83.

Monyoncho, R. M. (20I5). Perception of Corporate Governance Practices at the University of Nairobi. DBA Africa Management Review 5(I), 95-II2.

Moghadam, S. K., Jorge, N., and Pirzade, F. (20I7). Examine Barriers to Implementing Accounting Information System (AIS) at the University of Payam Noor in Khuzestan, Ilam and Lorestan. International Journal of Scientific Management and Development 5(6), 257-265.

Mutanga, O. (20I5). Linking Funding with Quality and Relevance of Higher Education. In Higher Education Funding Excellence Conference (pp. I-I3).

NAB Ghana. (20I5). Tertiary Education Statistics Report. NAB.

Newman, E., and Duwiejua, M. (20I5). Models for innovative funding of higher education in Africa - The case in Ghana. Towards innovative models for funding higher education in Africa, Association of African Universities, I-23.

NCTE. (2OI2). Sustainable Financing of Tertiary Education: Building Ghana's future. NCTE. 
OECD. (2016). Trends Shaping Education 2016. https://doi.org/http:// dx.doi.org/Io.I787/trends_edu- 20I6-en ISBN

Owusu-mensah, I. (20I5). Promoting Quality University Education in Ghana: The Challenges of Mentoring Private Universities. British Journal of Education, Society and Behavioural Science 8(2), IO4-II6. https://doi.org/10.9734/BJESBS/2015/17104

Rowlands, J. (20I7). University Governance Models. Academic Governance in the Contemporary University, III-I28.

Sazonov, S. P., Kharlamova, E. E., Chekhovskaya, I. A., and Polyanskaya, E. A. (20I5). Evaluating financial sustainability of higher education institutions. Asian Social Science 11(20), 34-40. https://doi.org/10.5539/ ass.viIn2op34

Shattock, M. (2013). University Governance, Leadership and Management in a Decade of Diversification and Uncertainty. Higher Education Quarterly 67(3), 2I7-233.

Shah, P. J. (2015). Regulatory structure of higher education in India. Centre for Civil Society Report.

Simms, L. J., Zelazny, K., Williams, T. F., and Bernstein, L. (20I9, March I4). Does the Number of Response Options Matter? Psychometric Perspectives Using Personality Questionnaire Data. Psychological Assessment. Advance online publicationhttp://dx.doi.org/I0.I037/pasoooo648

Teferra, D. (2013). Funding Higher Education in Africa: State, Trends and Perspectives (Vol. II). Palgrave Macmillan.

Teferra, D. (20I4). Charting African Higher Education - Perspectives at a Glance. International Journal of African Higher Education 1(I), 9-2I.

Tasopoulou, K., and Tsiotras, G. (2OI7). Benchmarking towards excellence in higher education. An International Journal 24(3), I-29. https://doi. org/IO.IIO8/BIJ-03-2016-0036

Triola, M. F. (20I7). Elementary Statistics (I3th ed.). Pearson.

UNESCO Institute for Statistics. (20I8a). Gross enrolment ratio by level of education between 20II and 20I6. Retrieved May 25, 2018 from http://uis.unesco.org/indicator/edu-part-er-ger

UNESCO Institute for Statistics. (20I8b). Tertiary Education. Retrieved February I, 20I8 from www.uis.unesco.org/country/GH

Williams, M. (20I5). The Relationship between Organizational Governance and Faculty Governance in Higher Education: A National Study of Shared Governance. Doctoral dissertation, Texas A and M University - Corpus Christi.

Yudkevich, M. (20I7). Academics and Higher Education Expansion. In Encyclopaedia of International Higher Education Systems and Institutions (pp. I3). https://doi.org/https://doi.org/IO.I007/978-94-OI7-9553I_58-I

\section{Appendix I}

Table 4. Participants' Demographic Characteristics

\begin{tabular}{|c|c|c|c|c|c|c|c|c|}
\hline \multirow{2}{*}{ Demographic characteristics } & \multicolumn{7}{|c|}{ Participating Institutions } & \multirow{2}{*}{$n$} \\
\hline & GIMPA & KNUST & UDS & UCC & UEW & UG & UPSA & \\
\hline \multicolumn{9}{|l|}{ Positions } \\
\hline Executive Level Management & 3 & 4 & 2 & 1 & 1 & & 3 & 14 \\
\hline Functional Level Management & 2 & 4 & 3 & 3 & 4 & 2 & 2 & 20 \\
\hline Middle Level Management & 3 & 3 & 4 & 3 & 3 & 2 & 1 & 19 \\
\hline \multicolumn{9}{|l|}{ Age Group } \\
\hline Under 30 & & & & & 1 & & & 1 \\
\hline $31-40$ & 4 & 2 & 1 & 2 & 2 & 1 & & 12 \\
\hline $41-50$ & 2 & 4 & 6 & 3 & 3 & 1 & 4 & 23 \\
\hline $51-60$ & 2 & 5 & 1 & 2 & 2 & 2 & 1 & 15 \\
\hline Over 60 & & & 1 & & & & 1 & 2 \\
\hline \multicolumn{9}{|l|}{ Gender } \\
\hline Female & 3 & 3 & 1 & & 1 & 1 & & 9 \\
\hline Male & 5 & 8 & 8 & 7 & 7 & 3 & 6 & 44 \\
\hline \multicolumn{9}{|l|}{$\begin{array}{l}\text { Academic/Professional } \\
\text { Qualifications }\end{array}$} \\
\hline Degree and Masters & 3 & 1 & 3 & 1 & 3 & o & 2 & 13 \\
\hline $\begin{array}{l}\text { Degree, Masters and } \\
\text { Professional Qualifications }\end{array}$ & 4 & 7 & 5 & 5 & 4 & 4 & 4 & 33 \\
\hline $\begin{array}{l}\text { Degree, Masters and PhD/ } \\
\text { Doctorate }\end{array}$ & 1 & 2 & 2 & & & & 1 & 6 \\
\hline $\begin{array}{l}\text { Degree, Masters and Other } \\
\text { Qualifications }\end{array}$ & 1 & & & & & & & 1 \\
\hline \multicolumn{9}{|l|}{ Professional Experience } \\
\hline $1-5$ years & 1 & & & & 2 & & & 3 \\
\hline 6-10 years & 4 & & 1 & 4 & 2 & 2 & & 13 \\
\hline $11-20$ years & 3 & 10 & 7 & 2 & 3 & 2 & 5 & 32 \\
\hline Over 20 years & & 1 & 1 & 1 & 1 & & 1 & 5 \\
\hline
\end{tabular}

Note: GIMPA = Chana Institute of Management and Public Administration KNUST $=$ Kwame Nkrumah University of Science and Technology UDS = University for Development Studies $U C C=$ University of Cape Coast

UEW = University of Education - Winneba $U \mathrm{U}=$ University of Ghana

UPSA = University of Professional Studies 